\title{
Green accounting: A Primer
}

\author{
Matthew N. O. Sadiku', Tolulope J. Ashaolu², Sunday S. Adekunte ${ }^{3}$, and Sarhan M. Musa1
}

\author{
${ }^{1}$ Roy G. Perry College of Engineering, Prairie View A\&M University, Prairie View, TX 77446 \\ ${ }^{2}$ College of Food Science, Southwest University, Tiansheng, Beibei, Chongqing, China \\ ${ }^{3}$ Community High School, Agada, Ogun State, Nigeria \\ E-mail: sadiku@ieee.org; ashaolut@gmail.com; ajayi-majebi@centralstate.edu; smmusa @pvamu.edu
}

*corresponding author details: Professor Matthew N. O. Sadiku; sadiku@ieee.org

\begin{abstract}
Green or environmental accounting is a new branch of accounting that provides for accounting the environmental impact. Unlike conventional accounting, green accounting accounts for the environment and its well-being. It factors environmental costs into the financial results of operations. It accounts for long-run effects of economic activity on the environment. This primer provides a brief introduction to green accounting.
\end{abstract}

Keywords: green accounting; environmental accounting; sustainable accounting

\section{INTRODUCTION}

Environmental changes are a global problem that requires a global solution. Recognizing the importance that the environment plays in our survival is compelling companies, organizations, and governments to create awareness among the masses about the importance of the environment and its well-being. Changes in the environment have a negative bearing on the environment and have the potential to slow down the economic growth. Like every component of modern business, accounting has not escaped the scrutiny of environmentalists [1].

Green accounting (also known as sustainable accounting or environmental accounting) has emerged as a measure of sustainable income level that can be secured without decreasing the stock of natural assets. Green accounting (GA) refers to combined environmental and economic accounting at national and corporate levels. It promotes a sustainable future for businesses as it incorporates green procurement and green $R \& D$ [2]. Green accounting is also called environmental accounting, resource accounting or integrated accounting.

\section{CONCEPT OF GREEN ACCOUNTING}

Conventional national accounting ignores the exhaustion of environmental resources and the degradation of the environment. Critics have argued that gross domestic product (GDP) (as a measure of national income) overlooks the environment factor and therefore needs to be revised to incorporate green accounting. Green accounting seeks to correct the aggregated indicator of national accounting, the GDP, from flaws that would otherwise make it a misleading policy tool. The result is known as "Green GDP," which seeks to overcome the weaknesses of GDP.

The term "environmental accounting" was introduced by economist and Professor Peter Wood in the 1980s. Environmental accounting or green accounting is an attempt to broaden the scope of all accounting frameworks including national accounts, financial accounting standards, and others used to assess economic performance. It is a major tool for assessing the costs and benefits of projects considering their environmental impact.

The UN issued a handbook on a System for integrated Environmental and Economic Accounting (SEEA) in 1993. Green accounting uses SEEA, which focuses on depletion of scarce natural resources. Such GA standards translate socially and environmentally responsible behavior into monetary terms.

The objectives of green accounting system include [3]:

1. To identify that part of the gross domestic product that reflects the costs necessary to compensate for the negative impacts of economic growth

2. To establish the linkage of physical resource accounts with monetary environmental accounts

3. To assess of environmental costs and benefits

4. To account for the maintenance of tangible resources

5. To measure the indicators of environmentally adjusted product and income

A green accounting system should be able to represent the views of optimists, pessimists, and those in between. It should be dynamic, flexible, and structured so that it can easily be updated as new information becomes available [4]. Green accounting is a means of cutting down environmental pollution as companies will be forced to place the costs related to environmental duty. Companies that adopt green accounting focus on the triple bottom line: people, planet, and profit.

Green accountants can advise clients on the impact that a business decision may have on the environment. They are to remedy and prevent the negative impact on the environment and help in waste minimization. 
They may need to simply incorporate green accounting features to upgrade the existing accounting software.

\section{APPLICATIONS}

Green accounting is the incorporation in the national accounts of an explicit recognition of the contribution of the environment to human wellbeing. It is an environmental policy that is relevant to all economic sectors. Green accounting helps all parts of the economic sectors to make informed decisions that support long term sustainable development. It involves saving resources, green products, and environmental production.

\section{- Companies}

Green accounting is a means of cutting down environmental pollution as companies will be forced to place the costs related to environmental duty. Every company is responsible to make the fullest possible use of its resources. An enterprise is a corporate citizen, who must be judged by its actions in relation to the environment and society [5]. Companies in almost all business sectors can expect to embrace green accounting within some years to come.

\section{- Agriculture}

This is a net contributor to the nation's economy. It affects the welfare generated by other sectors. Green accounts have been developed in countries with intensive agricultural production. This is designed to facilitate voluntary improvements in farm environmental performance. While agriculture can enhance natural capital, it also causes depreciation of natural capital like other sectors [6].

\section{- Manufacturing}

The manufacturing processes are direct sources of wastes, which are often disposed of in the environment. The program for the protection of the environment avoids manufacturing of products at the expense of damage to the environment [7]

\section{BENEFITS}

Going green accounting reduces social risk, environmental risk, political risk, market risk, business risk, and financial risk. It enhances the reputation of a company, enhances stakeholder appreciation, protects the company, and redeems the mistakes of corporations. The ultimate objective of the go green movement is to: (1) lower costs and increase revenues, profits, equity and corporate assets, (2) support long-term business sustainability and corporate profits; (3) increase prices or share value of company; and (4) encourage sustainable growth of enterprise [8]. Other benefits include [9]:

1. GA would enable governments to evaluate choices better without a bias against future generations, or a bias in favor of man-made assets as against natural assets.

2. Green Accounting is to adjust traditional measures of growth and to re-cast them as measures of sustainable growth. There it could be fair and true measure of the national wealth.

3. It would help in improving environmental performance, controlling costs and promote sustainability.

4. It would encourage the government as well as the corporate to invest in cleaner and efficient technologies.

5. It would facilitate forming informed decisions related to their business activities.

6. It would help in developing greener processes and products.

\section{CHALLENGES}

Although greening the national accounts has become popular in affluent countries, adopting green accounting is by no means easy. It is difficult to accurately measure the pollution level of each industry since all industries do not pollute the same amount. This makes it hard to set up a fair set of policies and determine penalties for polluters. Most part of the world is still unaware of green accounting. Other challenges include [9]:

1. GA is an evolving science and still under study.

2. There is no standard accounting method.

3. Comparison between two companies and two countries is not possible due to change in the method of accounting.

4. It mainly considers cost internal to the company and excludes cost to society.

5. It is not possible to value every component of natural capital and human capital in an accurate manner.

6. For valuation of natural resources consumed like decreasing forest cover, carbon gases emitted in the air, unbiased and true data would be required.

7. It is not possible draw conclusion in an easy way as it is a long-term process.

8. The cost involved in training staffs and employees is high.

\section{CONCLUSION}

Green accounting is the term for environmental and natural resource accounting. It is an accounting model that takes into account environmental interests. It is enjoying an unprecedented attention in both the academic and professional accounting communities. Although GA is an emerging field of study and practice; it is quickly gaining relevance because of its importance.

Green accounting is a policy that is relevant everywhere, the government of each nation must proactively promote environmental awareness and stress bringing green accounting practices to the forefront of accounting. Green accounting should be introduced in accounting curriculum [10]. It is the unavoidable trend. More information on green accounting can be found in books in [11-16].

\section{REFERENCES}

[1]D. B. Thornton, "Green accounting and green eyeshades," CA Magazine, vol. 126, no. 9, October 1993, pp.34-40.

[2] "Green accounting," Wikipedia, the free encyclopedia

https://en.wikipedia.org/wiki/Green_accounting

[3] S. Annwar, "Green accounting system- Objectives and importance," December 2018,

https://www.jagranjosh.com/general-

knowledge/green-accounting-system-objectives-andimportance-1545652441-1

[4] P. P. Craig and H. Glasser, "Transfer models for 'green accounting': An approach to environmental policy analysis for sustainable development," in National Research Council, Assigning Economic Value to Natural Resources. Washington DC: National Academy Press, chapter 5, 1994. 
[5] Manoj Yadav," Green accounting a review paper," https://www.researchgate.net/publication/3278830 32_Green_Accounting_a_Review_Paper/download

[6] A. Buckwell, "Green accounting for agriculture," Journal of Agricultural Economics, vol. 56, no. 2, 2005, pp. 187-215.

[7] A. M. Magablih, "The impact of green accounting for reducing the environmental cost in production companies," Journal of Modern Accounting and Auditing, vol. 13, no. 6, June 2017, pp. 249-265.

[8] A. Lako, "Ecological crisis and urgency of green accounting,"

https://www.researchgate.net/publication/3233880 47_Ecological_Crisis_and_Urgency_of_Green_Accounti ng

[9] L. Jolly, "Green accounting - a way to sustainable development," Sai Om Journal of Commerce \& Management, vol 1, no. 5, May 2014, pp. 44-47.

[10] R. K. Fleischman and K. Schuele, "Green accounting: A primer," Journal of Accounting Education, vol. 24, 2006, pp. 35-66.

[11] P. Bartelmus and E. K. Seifert (eds.), Green Accounting. Ashgate Publishing Co., 2003.

[12] A. Markandya and M. Tamborra (eds.), Green Accounting in Europe; A Comparative Study. Edward Elgar Publishing, vol. 2, 2005.

[13] A. Markandya and M. Pavan (eds.), Green Accounting in Europe - Four Case Studies. Springer Science+Business Media, 1999.

[14] C. Caraiani et al., Green Accounting Initiatives and Strategies for Sustainable Development. Business Science Reference, 2015.

[15] L. Karl-Gustaf and C. Z. Li, Green National Accounting and Sustainability. Edward Elgar Publishing, 2011.

[16] T. Aronsson, P. O. Johansson, and K. G. Löfgren, Welfare Measurement, Sustainability And Green National Accounting: A Growth Theoretical Approach. Edward Elgar, 1997.

\section{ABOUT THE AUTHORS}

Matthew N.0. Sadiku is professor emeritus in the Department of Electrical and Computer Engineering at Prairie View A\&M University, Prairie View, Texas. He is the author of several books and papers. His areas of research interests include computational electromagnetics and computer networks. He is a fellow of IEEE.

Tolulope J. Ashaolu is a researcher at Southwest University. He is the author of several papers and two books. His research interests include functional foods and food microbiology.

Sunday S. Adekunte is the principal of community high school, Agada, Nigeria. He holds a degree in animal production from Olabisi Onabanjo University, Ago-Iwoye. He is a fellow of Teachers Registration Council of Nigeria. His area of research interests includes education, agriculture, and security.

Sarhan M. Musa is a professor in the Department of Engineering Technology at Prairie View A\&M University, Texas. He has been the director of Prairie View Networking Academy, Texas, since 2004. He is an LTD Sprint and Boeing Welliver Fellow. 